\title{
PENGGUNAAN MODEL DISCOVERY LEARNING DENGAN METODE PERMAINAN PADA PEMBELAJARAN MATEMATIKA UNTUK MENINGKATKAN HASIL BELAJAR
}

\author{
Desi Rahmi \\ SMA Negeri 1 Sitiung \\ Email: rahmi.desi@gmail.com
}

\begin{abstract}
This classroom action research was carried out with the aim of seeing the improvement of students' mathematics learning outcomes using the discovery learning game method. After the research objectives were determined, this Classroom Action Research was carried out in class XI IIS 4 SMANegeri 1 Sitiung, located in Dharmasraya Regency, West Sumatra Province, following the steps: Planning, implementing actions, observing, and reflecting. The increase in student learning outcomes in the first cycle illustrates that students who reach the complete score increased to $61.13 \%$ which was originally only $38.7 \%$ in the pre-cycle. The increase in the percentage of students who completed the second cycle increased to $77.42 \%$.

Keywords: discovery learning model, game method
\end{abstract}

\begin{abstract}
Abstrak
Penelitian tindakan kelas ini dilaksanakan dengan tujuan untuk mengetahui peningkatan hasil belajar matematika peserta didik dengan menggunakan model pembelajaran discovery learning metode permainan. Setelah ditetapkannya tujuan penelitian, maka Classroom Action Research ini dilaksanakan di kelas XI IIS 4 SMANegeri 1 Sitiung yang terletak di Kabupaten Dharmasraya Provinsi Sumatera Barat, mengikuti langkahlangkah: Perencanan, Pelaksanaan tindakan, Observasi, dan Refleksi. Peningkatan hasil belajar peserta didik pada siklus satu menggambarkan bahwa peserta didik yang mencapai nilai tuntas meningkat menjadi $61,13 \%$ yang semula hanya $38,7 \%$ pada pra siklus. Kenaikan pesentase peserta didik yang tuntas di siklus dua meningkat menjadi $77,42 \%$.

Kata kunci: model pembelajaran discovery learning, metode permainan
\end{abstract}

\section{PENDAHULUAN}

Rendahnya hasil belajar peserta didik bukan sepenuhnya kesalahan peserta didik. Peranan guru juga sangat besar dalam menentukan keberhasilan peserta didik. Adapun faktor yang mempengaruhi proses pembelajaran adalah: 1) tujuan pembelajaran, 2) motivasi peserta didik, 3) guru, 4) materi pembelajaran, 5) metode yang digunakan, 6) media, 7) evaluasi, dan 8) situasi lingkungan. Berdasarkan beberapa pendapat di atas, faktor guru, metode atau pendekatan pembelajaran yang digunakan, fasilitas yang tersedia, kondisi-kondisi internal peserta didik seperti: tingkat kemampuan awal, minat belajar dan motivasi belajar sangat mempengaruhi tinggi rendahnya prestasi belajar peserta didik. Pemilihan metode pembelajaran oleh guru dapat juga mempengaruhi hasil belajar peserta didik. Hal lain yang menyebabkan rendahnya hasil belajar peserta didik adalah 
keterbatasan media, seperti : kurangnya buku sumber, tidak ada bahan ajar, penggunaan alat peraga yang kurang oleh guru.

\section{Belajar dan Pembelajaran Matematika}

Slameto (2003:2) bahwa "Belajar adalah proses yang dilakukan seseorang untuk memperoleh suatu perubahan tingkah laku yang baru secara kuseluruhan, sebagai hasil pengalamannya sendiri dalam interaksi dengan lingkunganya ".Menurut Nikson yang dikutip oleh Mulyardi (2003:3) mengemukakan bahwa "Pembelajaran matematika adalah upaya yang membantu peserta didik mengkontruksikan konsep-konsep atau prinsip-prinsip matematika dengan kemampuannya sendiri melalui proses internalisasi sehingga konsep atau prinsip itu terbangun kembali”.

Pembelajaran matematika bukan hanya mengandalkan teori belaka tetapi lebih mengutamakan penekanan konseptual. Pembelajaran matematika lebih bersifat sebagai kegiatan pemecahan masalah. Pelaksanaan pembelajaran matematika juga membutuhkan guru yang mengerti akan strategi pembelajaran yang baik. Strategi yang diterapkan hendaknya mampu memberikan kesempatan seluas-luasnya pada peserta didik untuk berpartisipasi aktif, dan menempatkan guru sebagai fasilitator yang memberikan kesempatan kepada peserta didik untuk menemukan dan menerapakan ide mereka dalam belajar, salah satu strategi yang digunakan adalah dengan menerapkan seperti pembelajaran aktif.

\section{Model Pembelajaran Discovery Learning}

Model pembelajaran adalah suatu rancangan atau suatu pola yang akan digunakan sebagai dalam proses pembelajaran. Pendapat Arens yang dikutip Trianto model pembelajaran mengacu pada pendekatan pembelajaran yang akan digunakan termasuk di dalam tujuan-tujuan pengajaran, tahap-tahap dalam kegiatan pembelajaran, lingkungan pembelajaran dan pengelolaan kelas (Azizah, 2017).

Dalam memilih suatu model pembelajaran, menurut (Trianto dalam Azizah, 2017) harus memiliki pertimbangan-pertimbangan, seperti: materi pelajaran, jam pelajaran, tingkat perkembangan kognisi peserta didik, lingkungan belajar, dan fasilitas pembelajaran yang tersedia, sehingga tujuan pembelajaran yang ditetapkan dapat tercapai. Sehingga dalam mengajarkan suatu konsep atau materi tertentu, tidak ada satu model pembelajaran yang lebih baik daripada model pembelajaran lainnya. Berarti untuk setiap model pembelajaran harus disesuaikan dengan konsep yang lebih cocok dan dapat dipadukan dengan model pembelajaran yang lain untuk meningkatkan hasil belajar peserta didik.

Ekaikhsanudin dalam http//www.ekaikhsanudin.net meyatakan berdasarkan fakta dan hasil pengamatan, penerapan pendekatan Discovery Learning dalam pembelajaran memiliki kelebihan-kelebihan dan kelemahankelemahan, antara lain:

Kelebihan Penerapan Discovery Learning.

a. Membantu siswa untuk memperbaiki dan meningkatkan keterampilanketerampilan dan proses-proses kognitif. Usaha penemuan merupakan kunci dalam proses ini, seseorang tergantung bagaimana cara belajarnya.

b. Pengetahuan yang diperoleh melalui model ini sangat pribadi dan ampuh karena menguatkan pengertian, ingatan dan transfer. 
c. Menimbulkan rasa senang pada siswa, karena tumbuhnya rasa menyelidiki dan berhasil.

d. Model ini memungkinkan siswa berkembang dengan cepat dan sesuai dengan kecepatannyasendiri.

e. Menyebabkan siswa mengarahkan kegiatan belajarnya sendiri dengan melibatkan akalnya dan motivasi sendiri.

f. Membantu siswa memperkuat konsep dirinya, karena memperoleh kepercayaan bekerja sama dengan yang lainnya.

g. Berpusat pada siswa dan guru berperan sama-sama aktif mengeluarkan gagasan-gagasan. Bahkan gurupun dapat bertindak sebagai siswa, dan sebagai peneliti di dalam situasi diskusi.

h. Membantu siswa menghilangkan skeptisme (keragu-raguan) karena mengarah pada kebenaran yang final dan tertentu atau pasti.

i. Siswa akan mengerti konsep dasar dan ide-ide lebih baik.

j. Membantu dan mengembangkan ingatan dan transfer kepada situasi proses belajar yang baru.

k. Mendorong siswa berpikir dan bekerja atas inisiatif sendiri.

1. Mendorong siswa berpikir intuisi dan merumuskan hipotesis sendiri.

m. Memberikan keputusan yang bersifat intrinsik.

n. Situasi proses belajar menjadi lebih terangsang.

o. Proses belajar meliputi sesama aspeknya siswa menuju pada pembentukan manusia seutuhnya.

p. Meningkatkan tingkat penghargaan pada siswa.

q. Kemungkinan siswa belajar dengan memanfaatkan berbagai jenis sumber belajar.

r. Dapat mengembangkan bakat dan kecakapan individu.

Kelemahan Penerapan Discovery Learning.

a. Menimbulkan asumsi bahwa ada kesiapan pikiran untuk belajar. Bagi siswa yang kurang pandai, akan mengalami kesulitan abstrak atau berpikir atau mengungkapkan hubungan antara konsep-konsep, yang tertulis atau lisan, sehingga pada gilirannya akan menimbulkan frustasi.

b. Tidak efisien untuk mengajar jumlah siswa yang banyak, karena membutuhkan waktu yang lama untuk membantu mereka menemukan teori atau pemecahan masalah lainnya.

c. Harapan-harapan yang terkandung dalam model ini dapat buyar berhadapan dengan siswa dan guru yang telah terbiasa dengan cara-cara belajar yang lama.

d. Pengajaran discovery lebih cocok untuk mengembangkan pemahaman, sedangkan mengembangkan aspek konsep, keterampilan dan emosi secara keseluruhan kurang mendapat perhatian.

e. Pada beberapa disiplin ilmu, misalnya IPA kurang fasilitas untuk mengukur gagasan yang dikemukakan oleh para siswa

f. Tidak menyediakan kesempatan-kesempatan untuk berpikir yang akan ditemukan oleh siswa karena telah dipilih terlebih dahulu oleh guru.

Dikarenakan pembelajaran Discovery Learning memiliki kelebihan yang dapat mengarahkan peserta didik kepada kebenaran yang final dan tertentu atau pasti maka dirasa tepat digunakan dalam pembelajaran matematika, karena matematika merupakan bagian dari ilmu pasti itu sendiri. 


\section{Metode Permainan}

Menurut Nuriah permainan matematika adalah suatu kegiatan yang menggembirakan dan dapat menunjang tercapainya tujuan pembelajaran (jiannuriah.blogspot.co.id). Metode permainan dalam pembelajaran matematika adalah cara untuk menyampaikan pelajaran matematika dengan sarana bermain. Metode permainan dalam pembelajaran dapat memberikan kesempatan bagi peserta didik untuk terlibat langsung dalam pembelajaran dan membuat peserta didik merasa senang terhadap matematika (Nuriah dalam jiannuriah.blogspot.co.id).

\section{Hasil Belajar Matematika}

Hasil belajar merupakan tolak ukur sejauh mana peserta didik menguasai suatu materi pelajaran, dan juga dapat mengukur sejauh mana peserta didik mengalami perubahan sehingga akibat dari proses belajar, peserta didik diharapkan memiliki kemampuan sebagai hasil dari proses belajar sesuai dengan indikator pencapaian hasil dari proses belajar sesuai denga indikator pencapaian hasil belajar pada Kurikulum Tingkat Satuan Pendidikan (KTSP). Hasil belajar yang dikuasai peserta didik haruslah berorientasi pada ketiga ranah tujuan pembelajaran di atas baik internal, sikap maupun psikomotor agar perubahan yang terjadi pada peserta didik benar-benar sebagai hasil dari pengalaman belajar yang telah dilaluinya. Pada kurikulum 2013 yang dinilai adalah ranah kognitif dan psikomotor (keterampilan). Adapun ranah kognitif diukur dengan tes yang dibuat guru bardasarkan pada kemampuan dasar yang dimiliki peserta didik dan nilai keterampilan diambil dari hasil unjuk kerja per kelompok.

\section{METODE PENELITIAN}

\section{Lokasi dan Waktu Penelitian}

Penelitian ini dilaksanakan di SMA Negeri 1 Sitiung kelas XI IIS 4, Dharmasraya. Penelitian ini dilaksanankan pada bulan Oktober sampai dengan bulan Desember tahun 2017 Penelitian ini dilakukan 5 kali pertemuan tatap muka dan 2 kali pemberian tes. Setiap tindakan diamati oleh seorang kolaborator. Subyek pada penelitian ini adalah peserta didik kelas XI IIS 4 SMA Negeri 1 Sitiung yang namanya terdaftar pada tabel daftar kelas XI IIS 4 semester 1 . Kelas XI IIS 4 dipilih karena hasil belajar matematika peserta didik kelas XI IIS 4 ini lebih rendah dari kelas lain. Ini berdasarkan pengamatan penulis dan dari hasil nilai rata-rata hasil belajar pada materi-materi sebelumnya.

\section{Prosedur kerja dalam penelitian}

Langkah-langkah pada penelitian ini adalah:

\section{Siklus 1}

Perencanaan dengan kegiatan: guru membuat RPP dan menetapkan seorang guru sebagai seorang kolaborator untuk membantu mengamati proses pembelajaran.

Tindakan

a. Peserta didik diminta membentuk kelompok sendiri yang terdiri dari 3-4 orang

b. Setiap kelompok diberi tugas yang sama dan diberi satu alat permainan yaitu ular tangga, peserta didik per kelompok diminta main permainan ular tangga dalam waktu yang ditentukan. Setelah waktu habis peserta didik diberi 
pertanyaan untuk menanamkan konsep translasi dan salah satu kelompok diminta menjawab ke depan kelas.

c. Setelah peserta didik mendapatkan konsep translasi, guru menerangkan cara mendapatkan rumus operasi untuk translasi dan setelah itu peserta didik diberi soal latihan.

d. Pada akhir siklus 1, tiap kelompok menuliskan hal apa yang sulit atau belum dipahami.

\section{Refleksi}

a. Kegiatan refleksi adalah kegiatan yang mengevaluasi semua aktivitas siklus yang sudah berjalan, untuk perbaikan kegiatan pada siklus berikutnya.

b. Refleksi dilakukan dengan cara berdiskusi dengan teman sejawat yang menjadi kolaborator.

\section{Siklus 2}

Pada prinsipnya sama dengan kegiatan siklus 1, tetapi permainan yang dilakukan adalah perang-perangan dengan melipat kertas, kelompok peserta didik hanya dengan teman sebangku dan pada siklus 2 ini peserta didik diberi bahan ajar yang berisi ringkasan materi agar peserta didik lebih paham dengan materi yang dipelajari.sumber untuk materi bangun ruang sisi datar ini sangat kurang, dilihat dari materi yang ada pada buku pegangan peserta didik. Karena itu penulis memberikan peserta didik bahan ajar yang berisi ringkasan materi yang akan dipelajari. Kegiatan pada siklus 2 ini merupakan perbaikan dari kekurangan yang ada pada siklus 1 .

\section{HASIL DAN PEMBAHASAN}

\section{Kondisi awal}

Sebelum pelaksanaan penelitian tindakan kelas ini, hasil belajar peserta didik tergolong rendah. Ini dapat dilihat dari hasil ulangan dan tugas-tugas pada Kompetensi Dasar sebelum diadakannya penelitian ini.

\section{Hasil penelitian dan pembahasan}

Setelah penelitian ini dilaksanakan didapat hasil dan pembahasan sebagai berikut :

\section{SIKLUS 1}

Siklus 1 dilaksanakan 2 kali pertemuan. Pertemuan 1 dilaksanakan pada hari Kamis tanggal 9 November 2017 pada jam ke 3-4. Pertemuan 2 dilaksanakan pada hari Kamis tanggal 16 November 2017 pada jam ke 3-4

Observasi

Selama proses pembelajaran berlangsung, masih ada peserta didik yang kurang serius bahkan terkesan hanya main-main. Hal ini dapat dilihat dari aktivitas yang dilakukan oleh peserta didik yang bersangkutan. Ada peserta didik yang kurang bersemangat. Ada juga beberapa kelompok yang tampak serius mendengar penjelasan guru dan melakukan permainan dengan semangat.. Ada juga kelompok yang terlihat sedikit kesulitan memahami maksud dari hubungan permainan dengan pelajaran. Dari 8 kelompok yang ada hanya 3 kelompok yang bisa memahami maksud dan tujuan dari permainan dengan pelajaran.

Gambar 1. Perbandigan rata-rata nilai, jumlah peserta didik yang tuntas dan persentase ketuntasan belajar klasilkal pada Pra Siklus dan Siklus 1 


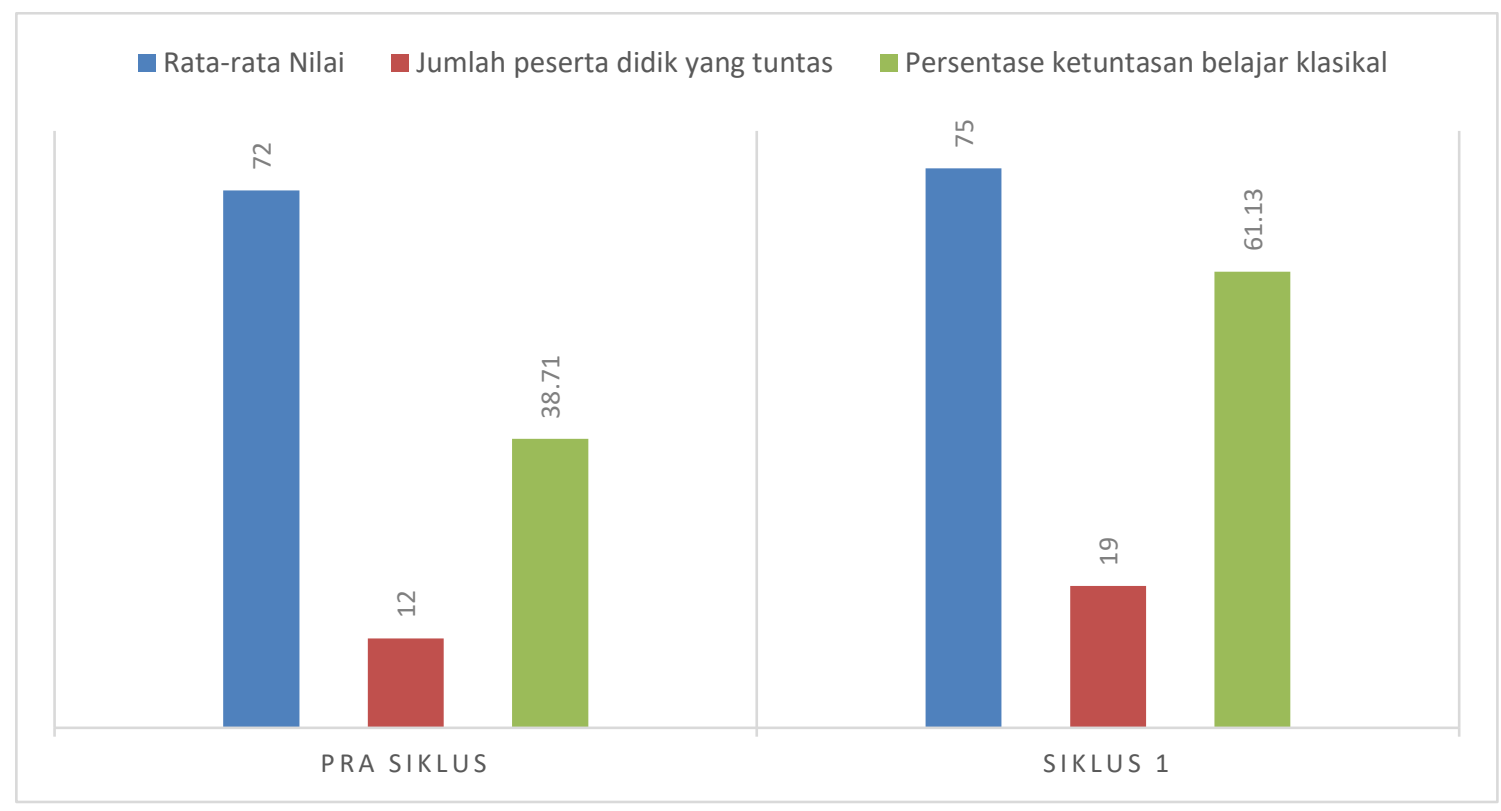

\section{PEMBAHASAN}

Setelah siklus 1 dilaksanakan peserta didik diberi soal ulangan akhir, ternyata nilai peserta didik terlihat ada sedikit peningkatan. Dari grafik di atas terdapat sedikit peningkatan pada rata-rata, jumlah peserta didik yang tuntas juga meningkat yang mengakibatkan persentase ketuntasan belajar secara klasikal juga meningkat. Setelah siklus 1 berakhir untuk siklus 2 guru membuatkan bahan ajar yang berisi materi yang akan dipelajari peserta didik. Jadi speserta didik lebih bisa memahami materi yang dipelajari.

Kesulitan yang ditemukan selama siklus 1 .

Tabel 1. Perbandingan keurangan atau hambatan dan alternatif pemecahan permasalahan pada Silus 1.

\begin{tabular}{|c|c|}
\hline Kekurangan atau hambatan & Alternative Pemecahan \\
\hline $\begin{array}{l}\text { Dari hasil observasi: } \\
\text { a. Untuk memakaikan prinsip permainan } \\
\text { pada pelajaran sudah dipahami peserta } \\
\text { didik yang menjadi kesulitan adalah } \\
\text { menentukan rumus dari dari hasil yang } \\
\text { diperoleh }\end{array}$ & $\begin{array}{l}\text { a. Menerangkan lagi dan } \\
\text { memakai bahan ajar } \\
\text { b. Menerangkan dan memberi } \\
\text { contah lagi }\end{array}$ \\
\hline $\begin{array}{l}\text { b. Peserta didik kurang memahami soal, } \\
\text { sehingga kesulitan/ragu dalam } \\
\text { menentukan titik asal dan hasil seperti } \\
\text { soal nomor } 1 \text { dan } 2 \text { banyak peserta didik } \\
\text { yang tidak dapat menjawab dengan benar. }\end{array}$ & $\begin{array}{l}\text { c. Diberi pengarahan dan } \\
\text { motivasi untuk belajar lebih } \\
\text { serius }\end{array}$ \\
\hline
\end{tabular}

\section{SIKLUS 2}

Siklus 2 dilaksanakan 3 kali pertemuan.

Pertemuan 1 dilaksanakan pada hari Sabtu tanggal 18 November 2017 pada jam ke $7-6$. Pertemuan 2 dilaksanakan pada hari Kamis tanggal 23 November 2017 pada jam ke 3 - 4. Pertemuan 3 dilaksanakan pada hari Kamis tanggal 30 November 2017 pada jam ke $3-4$. 


\section{Observasi}

Setelah pembelajaran dilakukan didapatkan hasil yang tidak jauh berbeda dari siklus 1. Peserta didik yang kurang serius belajar masih ada, meskipun untuk nilai ketertampilan atau aktivitas belajar meningkat.

Tabel 2. Nilai hasil tugas dan ulangan akhir pada Siklus 2

\begin{tabular}{|c|l|c|}
\hline No & Hasil tugas dan ulangan matematika & Siklus 2 \\
\hline 1. & Nilai tertinggi & 97 \\
2. & Nilai terendah & 58 \\
3. & Rata-rata nilai & 79 \\
4. & Peserta didik yang tuntas & 24 \\
5. & Peserta didik yang tidak tuntas & 7 \\
6. & Ketuntasan belajar klasikal dalam \% & 77,42 \\
7. & Jumlah peserta didik & 31 \\
\hline
\end{tabular}

Gambar 2. Pebandingan rata-rata nilai, jumlah peserta didik yang tuntas dan prenase ketuntasan belajar klasikal pada Siklus 2

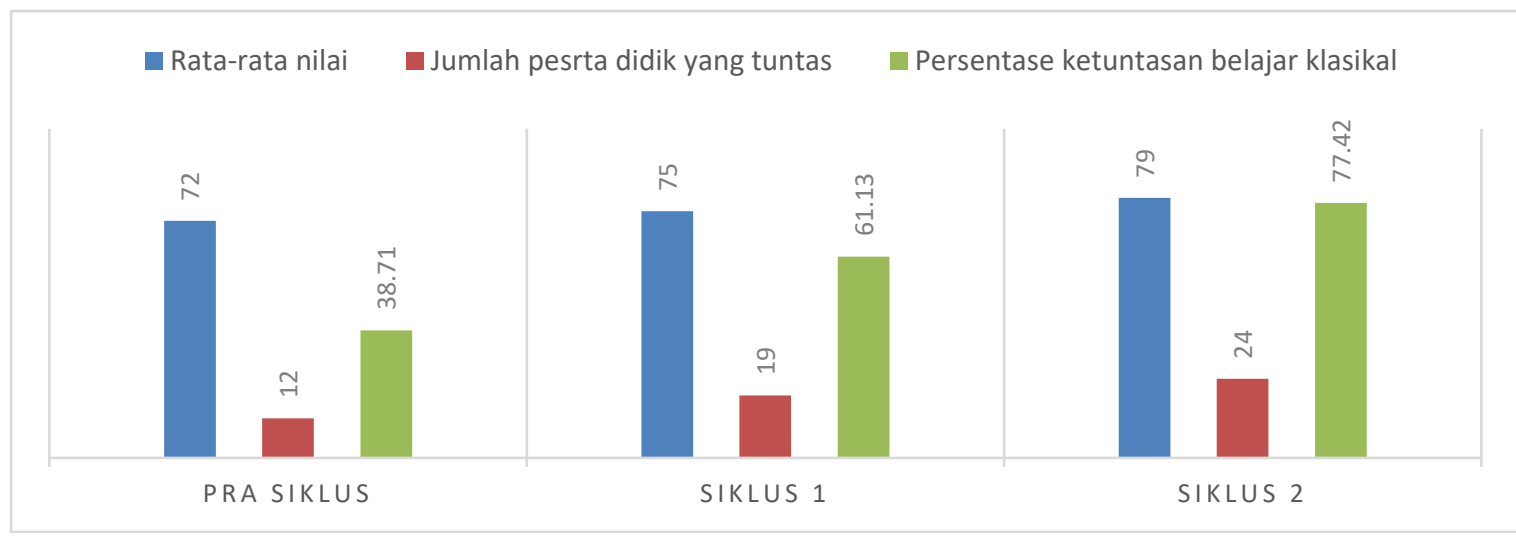

\section{HASIL PENELITIAN DAN PEMBAHASAN}

Terdapat peningkatan pada siklus 2 , baik rata-rata nilai, jumlah peserta didik yang tuntas dan persentase ketuntasan belajar klasikal. Siswa yang mendapat nilai 100 tidak ada, nilai yang paling tinggi hanya mencapai 97 dan itu pun hanya satu orang. Nilai tertinggi pada siklus 2 ini turun dari siklus 1 , nilai tertinggi pada siklus 1 adalah 99, sedangkan pada siklus 2 hanya 97, tapi secara keseluruhan nilai pesrta didik siswa meningkat dilihat dari rata-rata dan persentase ketuntasan peserta didik. Tetapi masih terdapat 7 orang peserta didik yang masih mendapatkan nilai dibawah KKM atau dibawah nilai 75. Secara klasikal pun belum tercapai ketuntasan belajar karena hanya mencapai $77,42 \%$, sedangkan yang diharapkan adalah $\geq 80 \%$. Namun secara keseluruhan dapat disimpulkan bahwa terjadi sedikit peningkatan dari hasil yang diperoleh sebelumnya.

Kesulitan yang ditemukan selama siklus 2

Tabel 3. Perbandingan keurangan atau hambatan dan alternatif pemecahan permasalahan pada Siklus 2

\begin{tabular}{|c|c|}
\hline Kekurangan atau hambatan & Alternative Pemecahan \\
\hline $\begin{array}{l}\text { Dari hasil observasi: } \\
\checkmark \quad \text { Untuk memakaikan prinsip permainan }\end{array}$ & Menerangkan lagi \\
\hline
\end{tabular}




\begin{tabular}{|l|l|}
\hline $\begin{array}{l}\text { pada pelajaran sudah dipahami peserta } \\
\text { didik, yang menjadi kesulitan adalah } \\
\text { menentukan rumus dari dari hasil }\end{array}$ & \\
$\begin{array}{l}\text { yang diperoleh } \\
\text { Peserta didik kesulitan/ragu dalam } \\
\text { menentukan rumus yang akan } \\
\text { digunakan untuk menyelesaikan soal } \\
\text { (ada } 6 \text { buah rumus untuk refleksi) }\end{array}$ & $>\begin{array}{l}\text { Menerangkan dan memberi contah } \\
\text { lagi }\end{array}$ \\
& $>\begin{array}{l}\text { Diberi pengarahan dan motivasi } \\
\text { untuk belajar lebih serius }\end{array}$ \\
\hline
\end{tabular}

Hasil yang diperoleh dari penelitian ini sangat terbatas, sebab yang dilihat hanya hasil tes akhir setiap siklus pada materi translasi dan refleksi. Kerja kelompok dan menyelesaikan tugas-tugas yang diberikan hanya untuk menambah pemahaman peserta didik.

\section{KESIMPULAN DAN SARAN}

Dari penerapan pembelajaran discovery learning dengan motede permainan dapat disimpulkan bahwa model discovery leaerning melalui metode permainan dapat meningkatkan hasil belajar peserta didik kelas XI IIS 4 yang mencapai nilai tuntas meningkat yang semula hanya $38,7 \%$ pada pra siklus menjadi $61,13 \%$ pada siklus satu dan menjadi $77,42 \%$ pada akhir siklus dua.

Di akhir laporan penelitian tindakan kelas tentang penerapan pembelajaran discovery learning dengan motede permainan dapat meningkatkan hasil belajar peserta didik di kelas XI IIS 4 SMA Negeri 1 Sitiung ini guru peneliti menyarankan menerapkan model discovery leaerning melalui metode permainan untuk meningkatkan hasil belajar peserta didik.

\section{DAFTAR PUSTAKA}

Azizah, Nur. 2017. Menulis PTK 4 X 2 Jam For Beginer Teachers. Pati: Fire Publisher (SaguSaku)

Departemen Pendidikan Nasional, 2004. Model-Model Pengajaran dalam Pembelajaran Sains, Direktorat Jenderal Pendidikan Dasar dan Menengah, Jakarta.

Hamdani. 2011. Strategi Belajar Mengajar. Bandung : Pustaka Setia.

Jiannuriah.blogspot.co.id. 2017. Didownload tanggal 26 Oktober 2017. Penerapan

Teori Belajar Dienes Yakni Metode Permainan Dalam Pembelajaran Matematika.

Muliyardi. 2002. Strategi Pembelajaran Matematika. Padang : FMIPA Universitas Negeri Padang.

Nana Sudjana. 2009. Dasar-Dasar Proses Belajar Mengajar. Bandung : Sinar Baru Algesindo

Roseno, Arjanggi dan Titin, Suprihartin. 2010. Metode pembelajaran teman sebaya meningkatkan hasil belajar berdasarkan regulasi diri. Jurnal Makara Sosial Vol. 14 No. 2 Desember 2010:91-97.

Slameto. 2003. Belajar dan Faktor-faktor yang mempengaruhinya. Jakarta : Rineka Cipta.

Wardhani, IGAK. 2010. Penelitian Tindakan Kelas. Jakarta : Universitas Terbuka 
Warsono. 2012. Pembelajaran Aktif Teori dan Asesmen. Bandung : Remaja Rosdakarya

Widiya, A. 2006. Penerapan Strategi Pembelajaran Kooperatif Yipe Jizsaw Terhadap Hasil Belajar Biologi Siswa Kelas VIII F SMPN Negeri I Bangkinang Kabupaten Kampar Tahun Ajaran 2005/2006. Skripsi Program Studi Biologi FKIP. UIR Pekanbaru.

Yusuf. 2005. Proses dan Hasil Belajar Biologi Pokok pembelajaran Kooperatif Tipe Jigsaw. http://www.damandiri.or.id/detail php.id238

Zulfan, S. 2001. Metode Penelitian. UNRI Press Pekanbaru.

www.academia.edu. 2017. Didownload tanggal 26 Oktober 2017. Metode Pembelajaran Matematika Bermain Sambil Belajar Penemuan Dalam Matematika.

http//www.ekaikhsanudin.net. 2017. Didownload tanggal 26 Oktober 2017. Model Pembelajaran Discovery Learning. 